Int. J. Dev. Biol. 59: 149-158 (2015)

doi: $10.1387 / \mathrm{ijdb} .150037 \mathrm{fs}$

\title{
Regulated cell death in diagnostic histopathology
}

\author{
FARUK SKENDERI ${ }^{1}$, SEMIR VRANIC ${ }^{1}$ and IVAN DAMJANOV*,2 \\ ${ }^{1}$ Department of Pathology, University of Sarajevo Clinical Center, Sarajevo, Bosnia and Herzegovina and ${ }^{2}$ Department of \\ Pathology and Laboratory Medicine, University of Kansas School of Medicine, Kansas City, Kansas, USA
}

\begin{abstract}
Regulated cell death (RCD) is a controlled cellular process, essential for normal development, tissue integrity and homeostasis, and its dysregulation has been implicated in the pathogenesis of various conditions including developmental and immunological disorders, neurodegenerative diseases, and cancer. In this review, we briefly discuss the historical perspective and conceptual development of RCD, we overview recent classifications and some of the key players in RCD; finally we focus on current applications of RCD in diagnostic histopathology.
\end{abstract}

KEY WORDS: regulated cell death, programmed cell death, apoptosis, histopathology, diagnostic markers

\section{Introduction}

Regulated cell death (RCD) is a controlled cellular process occurring in physiological and pathological conditions. It is essential for normal development, tissue integrity and homeostasis in multicellular organisms. Dysregulation of cell death routines leads to a variety of pathological conditions, including developmental and immunological disorders, neurodegenerative diseases, and cancer (Fuchs and Steller, 2011). In this review, following the recent recommendations of Nomenclature Committee on Cell Death (NCCD) (Galluzzi et al., 2014), we refer to the programmed cell death (PCD) in cases of physiological regulated cell death.

\section{Historical aspects}

The research field of cell death has been emerging since few decades ago. Though, the story of RCD begins as early as 1842, when Carl Vogt noticed dying cells in toad embryos (Vaux and Korsmeyer, 1999), and in 1885 when some of the distinct morphological aspects, as opposed to necrosis, were recognized and described as spontaneous cell death, named chromatolysis, by Walther Flemming (Majno and Joris, 1995). The discovery of tissue stains has enabled early researchers to encounter this phenomenon in many tissues, such as regressing follicles, lactating mammary glands or breast cancer (Majno and Joris, 1995), and eventually, the questions about the process opposite to mitosis and the regulation of tissue growth rose. In 1914 a German anatomist Ludwig Gräper gathered the existing knowledge and the results of his own experiments about the physiological elimination of cells, in an article that should had laid the foundations for the field, but unfortunately it did not attract much attention (Majno and Joris,
1995). Many years later more detailed descriptions and underlying mechanisms of programmed cell death were given by Glucksman in 1951, and Kerr, Lockshin and Williams in 1965 (Ameisen, 2002, Galluzzi et al., 2012, Kerr, 1965, Lockshin and Williams, 1965).

Kerr suggested two morphological types of cell death at that time, first being degenerative, essentially the necrosis, and the second, non-degenerative, which he had named "shrinkage necrosis" (Kerr, 1965, Kerr, 2002). Degenerative cell death was described as affecting groups of cells, including cell swelling and disruption of cell membranes, release of cytoplasm and inflammatory response. The non-degenerative cell death was affecting single or small clusters of cells, featured cell and nucleus shrinkage, preserved cell membrane, and no inflammatory cells were present. In the years that follow, shrinkage necrosis was observed in a wide range of physiological and pathological states, including embryogenesis, spermatogenesis, tissue remodeling during regression or healing, and cancer growth (O'Rourke and Ellem, 2000), eventually leading to concept of apoptosis (Kerr et al., 1972, Wyllie et al., 1980).

Apoptosis (Greek, falling of the leaves) was defined as an active, programmed and controlled cell deletion mechanism, which plays a complementary but opposite role to mitosis in regulation of cell population number, and can be triggered by both physiological and pathological stimuli (Kerr et al., 1972). The expansion of molecular biology tools has generated a new wave of research in this field, resulting in the identification of several specific genes and proteins

\footnotetext{
Abbreviations used in this paper: AI, apoptotic index; DLBCL, diffuse large B-cell lymphoma; GVHD, graft versus host disease; NCGD, Nomenclature Committee on Cell Death; PCD, programmed cell death; RCD, regulated cell death; TUNEL, terminal deoxynucleotidyl transferase (TdT)-mediated dUTP-biotin nick end-labeling.
}

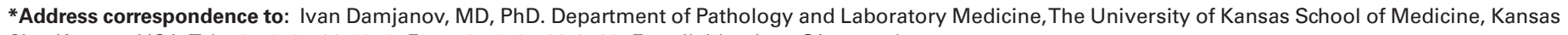
City, Kansas, USA. Tel: +01-913-588-9070. Fax: +01-913-588-8780. E-mail: Idamjano@kumc.edu
}

Accepted: 6 May 2015

ISSN: Online 1696-3547, Print 0214-6282 
involved in apoptosis. The studies of the development of nematode Caenorhabditis elegans (Brenner, 2003, Horvitz, 1999, Sulston et al., 1983) have greatly contributed to the understanding of the molecular basis of apoptosis and the authors were consequently awarded a Nobel Prize for Medicine in year 2002. Until recently apoptosis and PCD were used synonymously (Elmore, 2007).

Since 1994, the research in the field of cell death has greatly expanded (Fig. 1). The morphological characteristics of cell death were complemented by accumulating data on its biochemical and molecular properties. It became evident that RCD may not refer merely to apoptosis, but rather to a number of genetically regulated processes, resulting in one of the morphologically welldefined cell death types, namely apoptosis (Galluzzi et al., 2012, Ouyang et al., 2012), autophagic cell death (Shimizu et al., 2014) or necroptosis (Kitanaka and Kuchino, 1999, Vanden Berghe et al., 2014, Vandenabeele et al., 2010, Zhou and Yuan, 2014) (Table 1). In addition, several novel, tentative modalities emerged, yet to be more characterized (Table 2). The most surprising fact discovered recently was that necrosis, historically considered as the accidental cell death type, may occur in finely regulated manner called necroptosis (Kaczmarek et al., 2013).

\section{Regulated cell death modalities}

Rapid development and recognition of different types of cell death modalities were accompanied by inconsistent terminology used by various scientists and a need for clear definitions for the proper classification of cell death became evident. Initially, three types of cell death were proposed based on morphology (Schweichel and Merker, 1973). Proposed Type I, II and III of cell death were consistent with present concepts of apoptosis, autophagy, and necrosis, respectively (Kroemer et al., 2005). This classification has been longstanding, and due to the simplicity and availability of morphological versus biochemical methods of RCD detection, even today it is used in its modified form (Shimizu et al., 2014) (Table 1). In the meantime, many aspects of the process leading to cell death have been elucidated. Accordingly, cell death could be classified using different approaches including enzymological (involvement of nucleases and proteases), functional (programmed or accidental, pathological or physiological), immunological (immunogenic or non-immunogenic) (Galluzzi et al., 2007), and finally molecular criteria (Galluzzi et al., 2012). The Nomenclature Committee on Cell Death (NCCD) was formed in 2005 with the aim to propose unified criteria for the definition of cell death and different cell death morphologies (Kroemer et al., 2005).

NCCD has, up to date, released four sets of recommendations on classification of cell death, the first one published in 2005 (Kroemer et al., 2005), second in 2009 (Kroemer et al., 2009), third in 2012 (Galluzzi et al., 2012) and fourth in 2014 (Galluzzi et al., 2014). In the first round of recommendations the classification relied purely on morphological criteria (Galluzzi et al., 2007), and although many different underlying molecular mechanisms of cell death were known, available data was still not sufficient to clarify morphological and molecular correlations to overcome the widespread morphological classification. Subsequent NCCD classifications recommend accurate molecular definitions and precise molecular methods for detecting and quantifying the cell death (Galluzzi et al., 2012, Kroemer et al., 2009), moving towards less subjective interpretations and better reproducibility of the research results. In their most recent recommendations, NCCD proposes fundamentally two types of cell death: the accidental cell death (ACD) and the regulated cell death (RCD). The ACD occurs in an uncontrollable manner due to the extreme physical, chemical or mechanical stimuli followed by structural disintegration of the cell. The RCD is genetically regulated in both pathological and physiological conditions. When occurring in physiological conditions, the RCD is referred as programmed cell death (PCD) (Galluzzi et al., 2014).

Recent studies revealed that morphologically and biochemically distinct RCD subroutines are not linear. They are not confined to single molecular pathway, nor mutually exclusive, but rather a complex interaction and crosstalk exists between them (Amaral et al., 2010, Galluzzi et al., 2012, Hotchkiss et al., 2009). If single RCD pathway is defective or blocked the cell may continue by alternative one, such in a case of inhibition of apoptosis with caspase inhibitors, when cells may die by necroptosis (Degterev et al., 2005, Ondrouskova et al., 2008, Vandenabeele et al., 2006). A multitude of different factors including stress signal type and intensity, cell

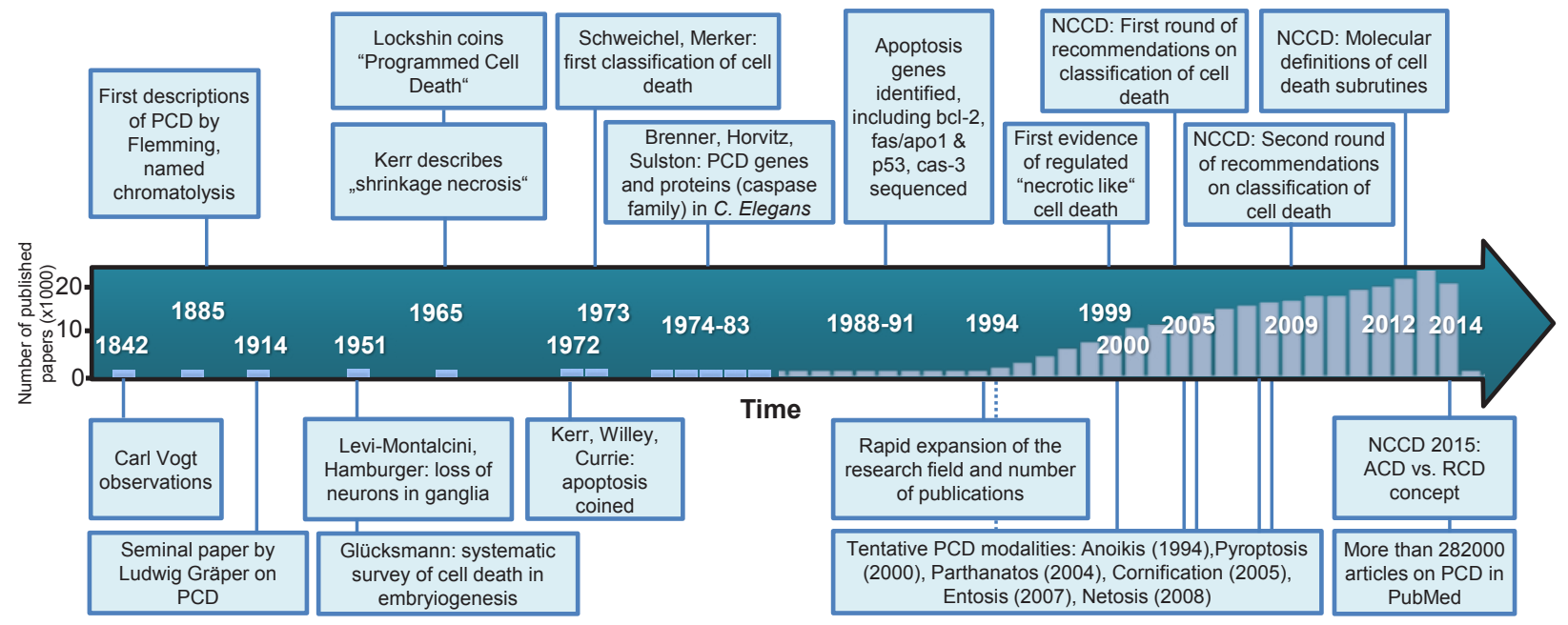

Fig. 1. The timeline of the progress of cell death research. $P C D$, Programmed cell death; NCCD, Nomenclature Committee on Cell Death; $A C D$, ACcidental cell death; RCD, Regulated cell death. 
type, and more to be discovered, may activate single or multiple RCD pathways, with complex interactions between pro- and antiapoptotic signals, and overlapping; determining whether and by which RCD pathway the cell will end its life (Galluzzi et al., 2012, Haupt et al., 2003).

\section{The important role of $\mathrm{p} 53$ protein and $\mathrm{Bcl}-2$ protein fam- ily in regulated cell death}

The $p 53$ protein is a tumor suppressor and transcriptional factor, and is situated at a crossroad of a signaling pathway network, which determines the fate of a stressed cell (Levine and Oren, 2009). It acts as a switch for transcription of sets of genes to perform the temporary cell cycle arrest and DNA repair, or permanent growth arrest and senescence, or apoptosis. The ability of p53 to induce the senescence or apoptosis represents its crucial tumor suppressor function (Pietsch et al., 2008), and it is not surprising that one of the most commonly mutated genes in cancer is the TP53, gene coding for p53 protein (Kumar et al., 2013). Owing to its roles, the inactive or missing p53, due to mutations, deletions, degradation or viral inhibition, leads to a wide instability of the genome, eventually resulting in malignant transformation of the cell. Recent studies report that the TP family members, namely TP63 and TP73 may contribute to, and in some instances induce the apoptosis (Pietsch et al., 2008) p53 stimulates an extensive network of signals that act through both intrinsic and extrinsic apoptotic pathways. The cell fate in intrinsic (mitochondrial) apoptotic pathway depends on predominance of pro-apoptotic Bax and BH3 subfamily proteins (Bax, Bak, Noxa, and Puma (Amaral et al., 2010)) or anti-apoptotic (Bcl-2, $\mathrm{Bcl}-\mathrm{X}_{\mathrm{L}}$, and other (Reed, 1997)) signaling proteins of Bcl-2 family, which converge on mitochondrial membrane. Upon cell stress p53 mediates transactivation of various pro-apoptotic Bcl-2 members or represses some of the anti-apoptotic genes (e.g., survivin, bcl-2) (Hoffman et al., 2002), or may post-translationally bind to Bcl-2 protein and inactivate it (Hemann and Lowe, 2006), which results in execution of intrinsic apoptosis. Modulation of extrinsic (death and dependence receptor) apoptotic pathway by p53 may occur by enhancing mRNA expression or protein trafficking of FAS receptor, which is tissue specific, or transactivation of others (e.g., DR5) (Haupt et al., 2003).

\section{Regulated cell death in normal development, homeo- stasis and disease}

Normal development and differentiation require well-regulated orchestration of programmed cell division and cell death. Apoptosis is the most common cell death program in the developing embryo and occurs in many organs, including brain, liver, eye, the lymphoid system, and limb. PCD has important role in organ and

\section{MORPHOLOGICAL AND BIOCHEMICAL CHARACTERISTICS OF CELL DEATH MODALITIES}

\begin{tabular}{|c|c|c|c|}
\hline & Cell Death modality & Biochemical characteristics & Morphological characteristics \\
\hline \multirow{9}{*}{ 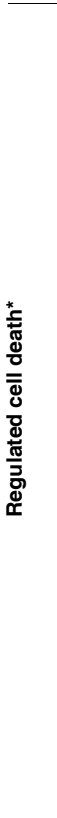 } & $\begin{array}{l}\text { Apoptosis } \\
\text { (Galluzzi et al., 2012) }\end{array}$ & & \\
\hline & Intrinsic & $\begin{array}{l}\text { Induced by various intracellular stress conditions (DNA damage, hypoxia, high } \\
\text { concentrations of } \mathrm{Ca}^{2+} \text {, severe oxidative stress). Modulated by Bcl-2 family of pro- and anti- } \\
\text { apoptotic proteins converging to mitochondrial membrane }\end{array}$ & \multirow{6}{*}{$\begin{array}{l}\text { Affects single cells or small clusters of cells. } \\
\text { Characterized by: } \\
\text { - } \text { rounding-up of cells } \\
\text { - reduction of cell volume (pyknosis) } \\
\text { - } \text { chromatin condensation } \\
\text { - } \text { nuclear fragmentation (karyorrhexis) } \\
\text { - plasma modification of organelles } \\
\text { - of the process } \\
\text { - formation of apoptotic bodies } \\
\text { - } \text { profulfment of apoptotic bodies by surrounding cells and } \\
\text { - in most instances no inflammation present }\end{array}$} \\
\hline & Caspase dependent & $\begin{array}{l}\text { Executed by MOMP } \rightarrow \text { release of IMS proteins (CYTC, Smac/DIABLO) } \rightarrow \text { apoptosome } \\
\text { formation } \rightarrow \text { caspase- } 9 \rightarrow \text { caspase- } 3 \text { pathway. }\end{array}$ & \\
\hline & Caspase independent & $\begin{array}{l}\text { Executed by MOMP } \rightarrow \text { release of IMS proteins (AIF, ENDOG, HTRA2) } \rightarrow \text { large-scale DNA } \\
\text { fragmentation, cleaving of cytosolic and cytoskeletal proteins }\end{array}$ & \\
\hline & Extrinsic & Caspase-dependent & \\
\hline & By death receptors & $\begin{array}{l}\text { Induced by binding of the death ligands (FASL/CD95L, TNF } \alpha \text {, TRAIL) to transmembrane } \\
\text { death receptors (FAS,TNFR1, TRAILR, DR5, other), executed by death receptor signaling } \\
\text { (DICS) and } \\
\text { - caspase } 8 \text { (or }-10) \rightarrow \text { caspase-3 pathway; or } \\
\text { - caspase- } 8 \rightarrow \text { tBID } \rightarrow \text { MOMP } \rightarrow \text { caspase- } 9 \rightarrow \text { caspase-3 pathway. }\end{array}$ & \\
\hline & By dependence receptors & $\begin{array}{l}\text { Induced by deprivation of ligands (e.g. NETRIN) binding to transmembrane dependence } \\
\text { receptors (e.g DCC, UNC5B). Executed by dependence receptor signaling and direct or } \\
\text { MOMP-dependent activation of caspase- } 9 \rightarrow \text { caspase- } 3 \text { pathway. }\end{array}$ & \\
\hline & $\begin{array}{l}\text { Autophagic cell death } \\
\text { (Green et al., 2011, Liu and } \\
\text { Levine, 2014) }\end{array}$ & $\begin{array}{l}\text { Distinct molecular pathway, involving autophagy modulator genes (e.g., VPS34, AMBRA1, } \\
\text { ATG5, ATG12, BCN1). } \\
\text { May be induced by nutrient starvation, DNA damage, organelle damage, etc. } \\
\text { Cytoplasmic organelles or protein aggregates are sequestered in double membrane vesicles } \\
\text { and delivered to lysosomes for degradation. } \\
\text { In stress-induced cases has cytoprotective role and favors cell survival. In normal } \\
\text { development favors cell death. }\end{array}$ & $\begin{array}{l}\text { Characterized by } \\
\text { - } \quad \text { lack of chromatin condensation } \\
\text { - } \quad \text { plasma membrane rupture } \\
\text { - no engulfment by adjacent cells } \\
\text { usually no inflammation present }\end{array}$ \\
\hline & $\begin{array}{l}\text { Necroptosis } \\
\text { (Kitanaka and Kuchino, 1999, } \\
\text { Vanden Berghe et al., 2014, } \\
\text { Zhou and Yuan, 2014) }\end{array}$ & $\begin{array}{l}\text { Induced by various stimuli including DNA damage, excitotoxins, ligation of death receptors } \\
\text { (e.g. TNFR1) or apoptosis deficient conditions. Regulated by RIP1 and RIP3. }\end{array}$ & \multirow{2}{*}{$\begin{array}{l}\text { Affects large groups of cells or parts of tissue. } \\
\text { Characterized by: } \\
\text { - gain of cell volume (oncosis) } \\
\text { - } \quad \text { swelling of organelles } \\
\text { - karyolysis, karyorrhexis, pyknosis } \\
\text { - } \quad \text { disrupted plasma membrane } \\
\text { - leakage of intracellular contents } \\
\text { - inflammation present }\end{array}$} \\
\hline 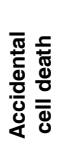 & $\begin{array}{l}\text { Necrosis } \\
\text { (Elmore, 2007) }\end{array}$ & $\begin{array}{l}\text { Induced by harsh external noxious stimuli, such as acute injury or infection, not showing } \\
\text { biochemical or morphological features of apoptosis or autophagy. }\end{array}$ & \\
\hline
\end{tabular}

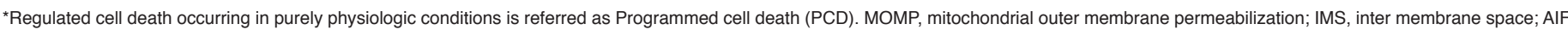

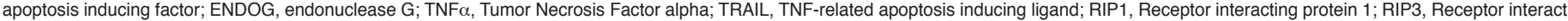

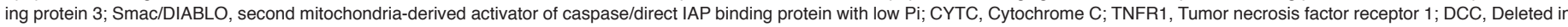
Colorectal Carcinoma; DISC, Death Inducing Signaling Complex 
tissue remodeling, the formation of hollow organs and the neural tube, and the generation of sexual organs (Jacobson et al., 1997), shaping forms (e.g. interdigital clefts) and separating, splitting or allowing tissue layers to fuse (Entezari et al., 2010, Penaloza et al., 2006). During development, PCD is particularly prominent in central nervous system and the immunogenic cells of the hematopoietic system. Both of these systems develop through overproduction of the cells. In the central nervous system, two- or three-fold number of overproduced neurons and glial cells are reduced through the death of those neurons that do not have appropriate synaptic connections (Nijhawan et al., 2000). In the immune system antigenspecific receptors are generated by random rearrangement of related structural genes and many potentially dangerous or useless immune cells are produced. Autoreactive cells are eliminated by overstimulation of death receptors, while useless cells, which lack appropriate receptor-ligand interactions or are deprived of stimulating factors, such as interleukin 2 (IL-2), are eliminated by dependence receptor apoptotic pathway (Opferman, 2008).

$\mathrm{PCD}$ is underlying the involution of hormone-dependent tissues upon hormone deprivation, such as endometrial cell breakdown during the menstrual cycle (Fig. 2A), and regression of the lactating breast after weaning; follicular atresia of postovulatory follicle; regulation of cell number in proliferating cell populations, such as intestinal crypt epithelia; elimination of cells that have served their

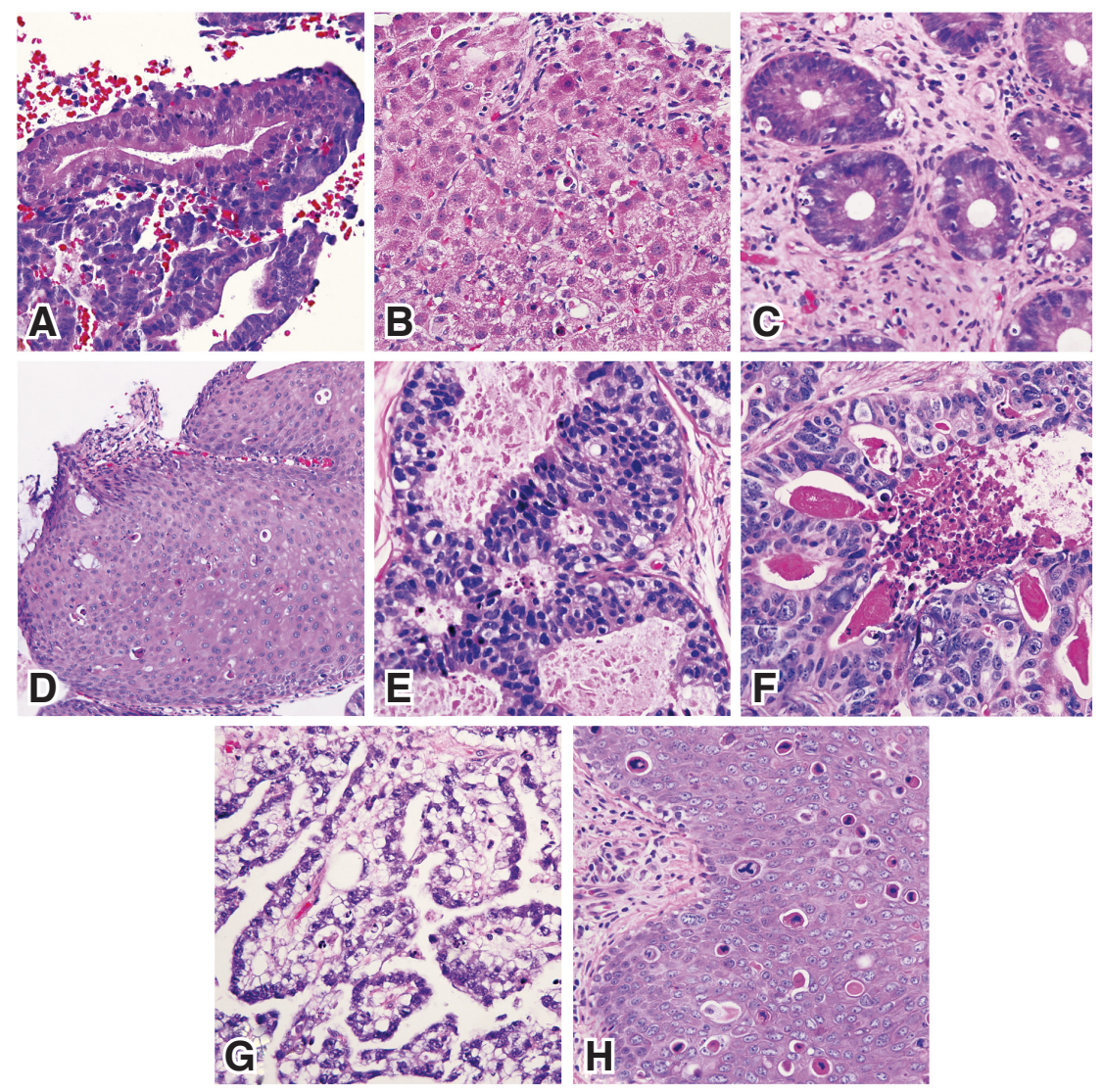

Fig. 2. Apoptosis and tissue turnover. Apoptosis regulates normal tissue turnover in physiological endometrial proliferation (A), but is observed in chronic liver disease (B), Graft versus host disease (C), HPV-related condylomas (D), ductal carcinoma in situ of the breast $(\mathbf{E})$, colon cancer $(\mathbf{F})$, embryonal carcinoma of the testis $(\mathbf{G})$, and squamous cell carcinoma of the skin $(\mathbf{H})$ function, as in a case of neutrophils in acute inflammation and lymphocytes at the end of immune response (Kumar et al., 2013). In addition, cell death machinery is used by cytotoxic T lymphocytes for killing of the pathogen-invaded cells (Vince and Silke, 2009).

Imbalances in apoptosis are underlying or accompanying number of pathologic conditions, and importantly, resistance to cell death is recognized as one of the hallmarks of cancer (Elmore, 2007, Hanahan and Weinberg, 2011) (Fig. 2E-G). Dysregulation may occur at any of the phases of cell death program through inhibition or overactivation of death receptors and ligands, mutations in p53, overexpression, inhibition or mutation of Bcl-2 pro- and anti-apoptotic proteins, reduced expression of caspases or overexpression of inhibitors of apoptosis (IAPs)(Vince and Silke, 2009, Wong, 2011).

Failure of differentiation between adjacent digits caused by the absence of apoptosis in the interdigital mesenchyme results in syndactyly, a congenital condition characterized by the fusion of adjacent fingers (Jordan et al., 2012). Exposure of intrauterine developing human embryo to noxious stimuli may cause cell stress and inappropriate or excess apoptosis, resulting in teratogenic effects (Brill et al., 1999, Entezari et al., 2010).

Increased apoptosis rate has been described in neurodegenerative diseases, such as Alzheimer's disease (Rohn, 2010), Parkinson's disease (Simunovic et al., 2009), amyotrophic lateral sclerosis (Pasinelli et al., 2000) and Huntington's disease (Ghavami et al., 2014, Kim et al., 2001, Mattson, 2000). Excess of apoptosis occurs in the cases of acute hypoxia and ischemia-reperfusion injury in cases of central nervous system insults (e.g., stroke) or acute and chronic heart diseases (Benchoua et al., 2001, Whelan et al., 2010) or chronic liver diseases (Fig. 2B) (Wang, 2014). Infectious agents have developed variety of mechanisms to interact with the host's defensive mechanisms in order to misuse them for spreading or evade the immune response. They may activate or inhibit apoptosis depending on the nature of the pathogen, cell type or pathogen abundance (Favaloro et al., 2012). Many viruses code apoptosis inhibitors, such as human papillomavirus (HPV) (Fig. 2D) (Jiang and Yue, 2014, McNees and Gooding, 2002) or anti-apoptotic protein homologues (Pauleau et al., 2007). Most of them cause excessive cell death by directly affecting RCD pathway proteins or indirectly, causing cell stress that may be detected by p53. In several autoimmune diseases, including pemphigus vulgaris (Deyhimi and Tavakoli, 2013), autoimmune lymphoproliferative syndrome (Madkaikar et al., 2011), rheumatoid arthritis, systemic lupus erythematosus and Hashimoto's thyroiditis (Eguchi, 2001, Nagata, 2007), abnormalities of cell death routines are reported. Importantly, resistance to RCD is one of the major mechanisms of malignant transformation of cell. Disturbances of $\mathrm{Bcl}-2$ family proteins are connected to B-cell lymphomas, Hodgkin lymphoma, breast cancer, lung cancer and kidney cancer (Egle et al., 2004, Gascoyne et al., 1997, Gobe etal., 2002, Han et al., 2002, Tawfik et al., 2012). Apoptosome inactivation is frequently found in several cancer 
TABLE 2

\section{TENTATIVE CELL DEATH MODALITIES OR PATHWAYS}

\begin{tabular}{l} 
Cell Death modality \\
\hline Mitotic catastrophe \\
(Vakifahmetoglu et al., 2008, \\
Vitale et al., 2011) \\
Cornification \\
(Candi et al., 2005) \\
Autosis \\
(Liu and Levine, 2014) \\
Anoikis \\
(Frisch and Francis, 1994) \\
Entosis \\
(Overholtzer et al., 2007) \\
Pyroptosis \\
(Brennan and Cookson, 2000) \\
Parthanatos \\
(Ame et al., 2004) \\
Netosis \\
(Remijsen et al., 2011)
\end{tabular}

Morphological and biochemical characteristics

Occurs during mitosis, induced by chromosomal or defects in mitosis machinery. It is an oncosuppresive mechanism that precedes cell death or senescence, rather than distinct cell death pathway. Affects single cells during mitosis. Characterized by micronucleation, multinucleation and apoptotic or necrotic like changes.

Cell death subroutine restricted to keratinocytes, necessary for the generation of stratum corneum of the epidermis, involving caspase-14

Autophagy-dependent, non-apoptotic form of cell death induced by autophagy-inducing peptides, starvation, and hypoxia-ischemia. Characterized by enhanced cell substrate adhesion, focal ballooning of the perinuclear space, and dilation and fragmentation of endoplasmic reticulum.

Death of adherent cells initiated by lack of cell-to-matrix interactions, executed by intrinsic apoptotic pathway.

Engulfment of a live cell by live neighboring cell. Engulfed cell dies through a lysosomal degradation within a phagosome.

Caspase-dependant cell death pathway involving early activation of caspase-1. Shows both apoptotic and necrotic morphological features. Induced by several types of bacteria (e.g., Salmonella typhimurium, Shigella flexneri, Listeria monocitogenes, Pseudomonas aeruginosa, and others) Caspase-independent cell death pathway. Induced by DNA damage. Involving the PARP family of enzymes (e.g., PARP1).

Cell death pathway restricted to granulocytes during their non-physiological stimulation and release of neutrophil extracellular traps (NETs, composed of nuclea chromatin, histones and granular antimicrobial proteins) which have antimicrobial activity. Shares the biochemical properties of autophagic cell death and regulated necrosis. types including melanoma, leukemias, glioblastomas, cervical carcinoma and Burkitt's lymphoma (Favaloro et al., 2012). Death receptor defects are also reported in many cancer types, notably the melanoma, hepatocellular carcinoma, T-cell leukemias, endometrial, lung and colon cancer (Hahne et al., 1996, Johnstone et al., 2008, Shin et al., 2002). Altered caspase activity and inhibition of AIFs are also reported in many studies.

The complexity of cell death regulation and the large numbers of molecules involved, require several approaches for developing therapeutics to modulate the pathway. Potential strategies include, but are not limited to small molecules that inhibit or activate specific proteins involved in the pathway, antisense oligonucleotides directed against specific genes involved in cell death, fusion proteins that can activate or block cell membrane receptors to modulate the pathway, mitochondria specific agents, or modified nanoparticles that activate apoptosis (Cho, 2014, Huang et al., 2013, Murphy et al., 2003a, Murphy et al., 2003b). Eventually, many of the potential therapeutic agents reached phase I and II clinical trial (Wong, 2011).

\section{Methods to detect regulated cell death}

With the recent advances in biotechnology, a number of methods have become available for detection and quantification of specific cell death subroutines. Morphological methods have been dominating for years, due to their availability and simplicity. However, because of molecular differences between morphologically similar RCD subroutines, the NCCD recommended shift from morphological to molecular assays for detection and quantification of cell death (Galluzzi et al., 2012). Nevertheless, both morphological and molecular methods have their advantages and disadvantages, which are beyond the scope of this review. Broadly, methods for detecting the RCD are based on cytomorphological features, detection of caspases, cleaved substrates, regulators and inhibitors, DNA fragmentation, plasma membrane alterations and mitochondrial assays. Different technologies may be employed and they include transmission electron microscopy (TEM), standard light microscopy, immunohistochemistry and special stains, (immuno)fluorescent or luminescent assays, DNA electrophoresis, flow cytometry, western blot, or these technologies may be combined to achieve more specific results (Holdenrieder and Stieber, 2004, Otsuki et al., 2003). Recently the technology of live cell imaging has been gaining more attraction.

Cytomorphological detection of apoptosis, augmented by immunohistochemical markers, is commonly used in research and diagnostic histopathology. A set of useful immunohistochemical markers may be used to detect apoptotic cells in their early phase, when morphological changes are still unremarkable (Table 3). Those markers improved the major drawback of the morphological approach that was related to detection of apoptosis in relatively narrow time window from development of morphological signs to dissolution and removal of the cell. Some of the specific immunohistochemical markers of apoptosis will be discussed later in the context of diagnosis or prognosis.

Morphological approach was combined with detecting DNA fragmentation in TUNEL (terminal deoxynucleotidyl transferase (TdT)-mediated dUTP-biotin nick end-labeling) assay (Ito and Otsuki, 1998). Labeled UTP is added to the $3^{\prime}$-end of the DNA fragments using terminal transferase. Subsequently, the dUTP can then be labeled with different probes to allow detection by light or fluorescence microscopy. TUNEL assay is not entirely specific for apoptosis, as it can detect DNA fragments in necrosis or cell undergoing DNA repair (Otsuki et al., 2003). Apoptosis may be detected by DNA isolation and agarose gel electrophoresis, which shows characteristic DNAfragments making DNA ladder. However, because the DNA fragmentation occurs in late stages, and it is not specific for particular RDC modality, it was depreciated by NCCD (Galluzzi et al., 2012).

Annexin $\mathrm{V}$ is a calcium-dependent protein that preferentially binds the phosphatidylserine, with high affinity. Conjugation of annexin $\mathrm{V}$ with a reporting system enables its detection on the membrane of the dying cell (van Heerde et al., 2000). However, phosphatidylserine translocation lacks the specificity and may occur in both apoptosis and necrosis. Combining this assay with nucleic acid dyes, which stain the DNA of cells with disrupted membrane, i.e. necrotic cells, may distinguish between two death modalities.

Mitochondrial assays measure mitochondrial permeability transition (MPT), depolarization of the inner mitochondrial membrane, $\mathrm{Ca}^{2+}$ fluxes, mitochondrial redox status, and reactive oxygen 


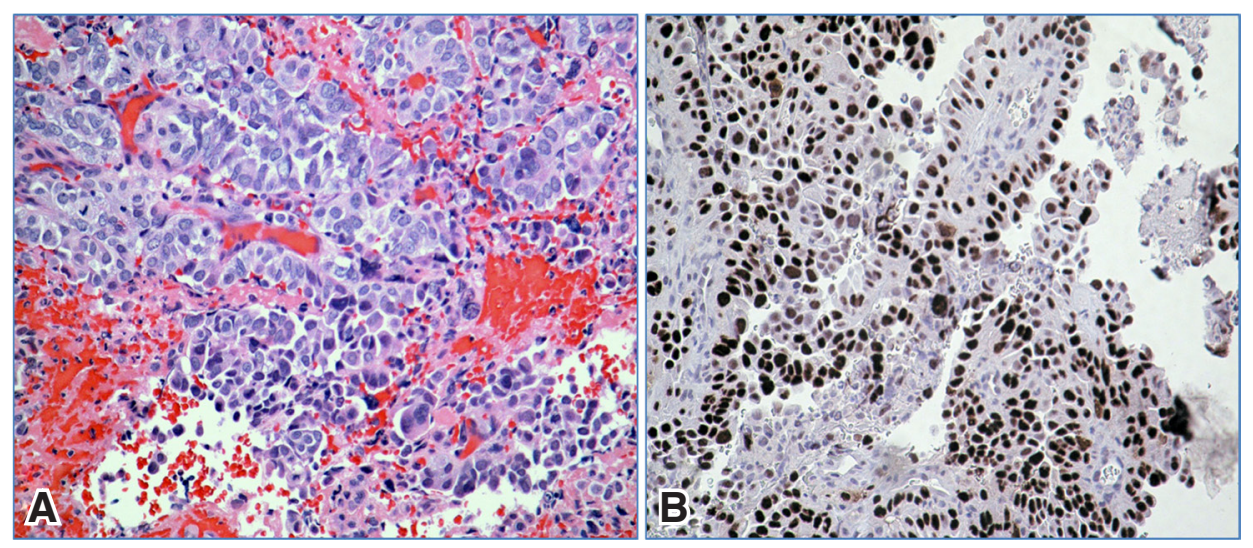

Fig. 3. High-grade serous adenocarcinoma of the endometrium (Hematoxylin and Eosin) (A) was diffuse and strong positive for p53 protein (B) (10x).

species. Also, the cytochrome $c$ release or $\mathrm{Bcl}-2$ family proteins at mitochondrial membrane may be detected by using confocal microscopy (Elmore, 2007).

\section{Diagnostic implications}

Although significant advances have been made in decrypting the programs of cell death, identifying the key players and potential therapeutic targets, the diagnostic, prognostic and predictive value of the biomolecules involved in RCD has been so far of limited extent.

The value of apoptotic index (Al) in diagnosis or prognosis has been studied in many cancer types (Becker et al., 2014, Fu et al., 2014, Gkogkou et al., 2014, Kuriyama et al., 2002, Ribeiro Mde et al., 2004, Richter et al., 2002, Wu et al., 2013), but the results were controversial. Further, Al was investigated as a predictor of chemotherapy response in gastric carcinoma (Jia et al., 2012, Wu et al., 2014a) or radiotherapy response in cervical cancer (Bhosle et al., 2005), and breast cancer (Burcombe et al., 2005). Some of the studies found Al to be useful alone or in combination with other prognostic factors, while others failed to demonstrate that utility. Of non-neoplastic diseases, the estimation of apoptosis has found its diagnostic utility in the evaluation of graft versus host disease (GVHD). Acute phase of GVHD is defined as onset of severe abdominal symptoms including diarrhea, bleeding, vomiting, and abdominal pain with a histologic evidence of GVHD within 100 days of transplant or donor lymphocyte infusion (Ross and Couriel, 2005, Thompson et al., 2006). Colon is typically involved, and biopsy of the distal part of colon shows apoptotic bodies that are required to make the diagnosis of GVHD (Ross, 2005) (Fig. 2C). Other parts of the gastrointestinal system can be involved as well. Skin and liver changes are also common features of this syndrome.

One of the most relevant diagnostic markers related to apoptosis is Bcl-2 protein. Bcl-2 has been found to be overexpressed in follicular center B-cell lymphoma due to the specific $t(14 ; 18)$ translocation. $\mathrm{Bcl}-2$ overexpression may well be seen in a subset of other B-cell lymphoproliferative diseases including chronic lymphocytic leukemia, diffuse large B-cell lymphoma and mantle cell lymphoma as a consequence of hypo-methylation of the bcl-2 promoter or the loss of the specific miRNAs (Kelly and Strasser, 2011). In all cases, immunohistochemistry and in-situ hybridization assays may detect specific alterations of $B C L 2$. Bcl-6 is

TABLE 3

\section{BIOMARKERS OF RCD USED IN DIAGNOSTIC AND RESEARCH HISTOPATHOLOGY}

\begin{tabular}{|c|c|c|}
\hline Marker & Type & Use \\
\hline $\begin{array}{l}\text { Apoptotic } \\
\text { index (AI) }\end{array}$ & Diagnostic & Diagnostic utility in GVHD (Ross, 2005). Prognostic utility controversial. \\
\hline $\mathrm{Bcl}-2$ & $\begin{array}{l}\text { Diagnostic, } \\
\text { prognostic }\end{array}$ & $\begin{array}{l}\text { Anti-apoptotic protein. Distinguishing follicular hyperplasia of lymph node from follicular lymphoma (Ozsan et al., 2011, Weinberg et al., 2009); Detecting immature } \\
\text { enteric ganglion cells in pediatric intestinal pseudo-obstruction (Park et al., 2005); Diffuse large cell lymphoma: possible adverse prognostic factor (Berglund et al., } \\
\text { 2005, lqbal et al., 2011); Myelodysplastic syndrome: increased expression associated with progression; Possible prognostic value in early stage breast } \\
\text { cancer(Dawson et al., 2010) }\end{array}$ \\
\hline Bcl-6 & $\begin{array}{l}\text { Diagnostic, } \\
\text { prognostic }\end{array}$ & $\begin{array}{l}\text { Differential diagnosis of small B-cell lymphoma. Follicular lymphoma is bcl-6 (and CD10) positive whereas other small B-cell lymphomas are usually negative } \\
\text { (Dogan et al., 2000). In difficult cases of follicular lymphoma, bcl-6 can identify an interfollicular component. } \\
\text { Important prognostic marker in DLBCL, where CD10, bcl-6 and MUM1/IRF4 are used to identify germinal center and activated B-cell phenotypes (Hans et al., } \\
\text { 2004). } \\
\text { Valuable in distinguishing classical Hodgkin lymphoma from nodular lymphocyte predominant Hodgkin lymphoma (NLPHL). The Reed-Sternberg cells of classical } \\
\text { Hodgkin lymphoma are bcl-6 negative whereas the large cells of NLPHL are bcl-6 positive (Kraus and Haley, 2000). }\end{array}$ \\
\hline p53 & $\begin{array}{l}\text { Diagnostic, } \\
\text { prognostic }\end{array}$ & $\begin{array}{l}\text { Tumor suppressor gene. Used to differentiate malignant conditions, which often show p53 positivity (carcinoma in situ of urothelium and other sites, invasive } \\
\text { carcinoma) from reactive and metaplastic conditions which are usually p53 negative (McKenney et al., 2001). Useful to distinguish uterine serous carcinoma (p53+) } \\
\text { from endometrioid carcinoma (usually p53-). Possible predictive value in thymic neoplasms (Khoury et al., 2009). Unfavourable prognosis biomarker in esophageal } \\
\text { SCC (Xu et al., 2014). p53 expression in upper urinary tract urothelial carcinoma was correlated with advanced pathologic stage, high histologic grade and female } \\
\text { gender (Lee et al., 2014) }\end{array}$ \\
\hline Fas & Prognostic & $\begin{array}{l}\text { Reduced Fas expression is a poor prognostic factor for breast carcinoma, colorectal carcinoma, retinoblastoma and urothelial carcinoma (Botti et al., 2004, } \\
\text { Shanmugam et al., 2003, Wang et al., 2006, Yamana et al., 2005). Reduced Fas expression is a favorable prognostic factor in primary nodal diffuse large B-cell } \\
\text { lymphoma and subcutaneous panniculitis-like lymphoma (Eser et al., 2006, Takeshita et al., 2004) }\end{array}$ \\
\hline FasL & Diagnostic & Positive in Reed-Sternberg cells of Hodgkin's lymphoma (nodular sclerosis and mixed cellularity (Verbeke et al., 2001) \\
\hline $\begin{array}{l}\text { Active } \\
\text { caspase-3 }\end{array}$ & Apoptosis marker & Immunohistochemical marker of apoptosis (Gown and Willingham, 2002, Jeruc et al., 2006, Sabine et al., 2012) \\
\hline Caspase-7 & Apoptosis marker & Immunohistochemical marker of colonic carcinoma (Bressenot et al., 2009, Palmerini et al., 2001) \\
\hline Caspase-8 & Apoptosis marker & Marker of initiation of apopotosis (Bressenot et al., 2009, Cho et al., 2010, Palmerini et al., 2001, Xu et al., 2008) \\
\hline $\begin{array}{l}\text { Cleaved } \\
\text { PARP }\end{array}$ & Apoptosis marker & $\begin{array}{l}\text { Marker of apoptosis and paranathos. Cleaved by caspase-3. Poly (ADP-ribose) polymerase (PARP) is a nuclear enzyme involved in DNA repair (Donizy et al., } \\
2013 \text {, Sulzyc-Bielicka et al., 2012, Wu et al., 2014b) }\end{array}$ \\
\hline Annexin V & Apoptosis marker & Marker of early phase of apoptosis. Binds to translocated phosphatydilseryne on the outer plasma membrane layer (Gerber et al., 2000) \\
\hline
\end{tabular}


another important the $\mathrm{Bcl}$ family-related protein with a significant diagnostic and prognostic utility, particularly in hematopathology. Bcl-6 nuclear positivity indicates follicle cell origins in lymph node. Its over-expression is frequently observed in follicular lymphoma, diffuse large B-cell lymphoma (DLBCL) and Burkitt's lymphoma due to the underlying genetic alterations (e.g. translocations) that affect 3q27 locus (Chaganti et al., 1998). Lymphomas belonging to the subset of DLBCL that lack 3q27 rearrangements frequently acquire mutations in BCL6 promoter regions.

p53 protein has had a limited diagnostic utility although its overexpression correlates with the tumor differentiation (grade) and aggressiveness. In diagnostic pathology, it has been primarily used to discriminate between atypical (neoplastic) and reactive (non-neoplastic) proliferation (e.g. urothelial proliferation); to evaluate the extent of dysplastic changes (e.g. Barrett esophagus, dysplastic changes in inflammatory bowel disease, anal intraepithelial neoplasia, progression of squamous cell dysplasia of the respiratory epithelium (Demirovic et al., 2014, Gattuso, 2009); to distinguish between the histotypes (serous that is typically p53+vs. endometrioid carcinoma of endometrium/ovary, usually p53-) (Fig. 3) (Macwhinnie and Monaghan, 2004). A protein that inhibits p53 named Mdm2 (Murine Double-Minute 2) has also yielded diagnostic utility as it has been found to be specific for liposarcomas due to the MDM2gene amplification (detected by in-situ hybridization assays) with a good correlation with Mdm2 protein status determined by immunohistochemistry (Hav et al., 2011). In addition, exposure of neoplastic cells to radiation- or chemotherapy agents may trigger apoptosis that is induced by DNA damage and activation of p53 protein (Kemp et al., 2001).

As previously mentioned, apoptosis is a core mechanism of neuron cell death in various neurodegenerative diseases including Parkinson's disease, Alzheimer's disease, Huntington's disease, amyotrophic lateral sclerosis as well as in stroke (Mattson, 2000), but diagnostic utility of apoptosis in these conditions is very limited.

\section{Conclusions}

A tremendous progress has been achieved in the last few decades in revealing the secrets of regulated cell death. Several molecular pathways and their interconnections build a complex cell signaling network with a numerous genes and proteins involved, to serve a function of proper tissue development and homeostasis. Dysregulation of these complex molecular mechanisms is involved in the pathogenesis of various disorders, including cancer. Therapeutical modulation of cell death routines may have wide implication on many of the diseases. Yet, the diagnostic utility of genes and proteins involved in regulated cell death is still of limited value in histopathology.

\section{References}

AMARAL, J.D., XAVIER, J.M., STEER, C.J. and RODRIGUES, C.M. (2010). The role of p53 in apoptosis. Discov Med 9: 145-152.

AME, J.C., SPENLEHAUER, C. and DE MURCIA, G. (2004). The PARP superfamily. Bioessays 26: 882-893.

AMEISEN, J.C. (2002). On the origin, evolution, and nature of programmed cell death: a timeline of four billion years. Cell Death Differ 9: 367-393.

BECKER, M., MULLER, C.B., DE BASTIANI, M.A. and KLAMT, F. (2014). The prognostic impact of tumor-associated macrophages and intra-tumoral apoptosis in non-small cell lung cancer. Histol Histopathol 29: 21-31.
BENCHOUA, A., GUEGAN, C., COURIAUD, C., HOSSEINI, H., SAMPAIO, N., MORIN, D. and ONTENIENTE, B. (2001). Specific caspase pathways are activated in the two stages of cerebral infarction. J Neurosci 21: 7127-7134.

BERGLUND, M., THUNBERG, U., AMINI, R.M., BOOK, M., ROOS, G., ERLANSON, M., LINDEROTH, J., DICTOR, M., JERKEMAN, M., CAVALLIN-STAHL, E. et al., (2005). Evaluation of immunophenotype in diffuse large B-cell lymphoma and its impact on prognosis. Mod Pathol 18: 1113-1120.

BHOSLE, S.M., HUILGOL, N.G. and MISHRA, K.P. (2005). Apoptotic index as predictive marker for radiosensitivity of cervical carcinoma: evaluation of membrane fluidity, biochemical parameters and apoptosis after the first dose of fractionated radiotherapy to patients. Cancer Detect Prev 29: 369-375.

BOtTI, C., BUGLIONI, S., BENEVOLO, M., GIANNARELLI, D., PAPALDO, P., COGNETTI, F., VICI, P., DI FILIPPO, F., DEL NONNO, F., VENANZI, F.M. et al., (2004). Altered expression of FAS system is related to adverse clinical outcome in stage I-II breast cancer patients treated with adjuvant anthracycline-based chemotherapy. Clin Cancer Res 10: 1360-1365.

BRENNAN, M.A. and COOKSON, B.T. (2000). Salmonella induces macrophage death by caspase-1-dependent necrosis. Mol Microbiol 38: 31-40.

BRENNER, S. (2003). Nature's gift to science (Nobel lecture). Chembiochem 4 683-687.

BRESSENOT, A., MARCHAL, S., BEZDETNAYA, L., GARRIER, J., GUILLEMIN, F. and PLENAT, F. (2009). Assessment of apoptosis by immunohistochemistry to active caspase-3, active caspase-7, or cleaved PARP in monolayer cells and spheroid and subcutaneous xenografts of human carcinoma. $J$ Histochem Cytochem 57: 289-300.

BRILL, A., TORCHINSKY, A., CARP, H. and TODER, V. (1999). The role of apoptosis in normal and abnormal embryonic development. JAssist Reprod Genet 16:512-519.

BURCOMBE, R.J., MAKRIS, A., RICHMAN, P.I., DALEY, F.M., NOBLE, S., PITTAM, M., WRIGHT, D., ALLEN, S.A., DOVE, J. and WILSON, G.D. (2005). Evaluation of ER, PgR, HER-2 and Ki-67 as predictors of response to neoadjuvant anthracycline chemotherapy for operable breast cancer. Br J Cancer 92: 147-155.

CANDI, E., SCHMIDT, R. and MELINO, G. (2005). The cornified envelope: a model of cell death in the skin. Nat Rev Mol Cell Biol 6: 328-340.

CHAGANTI, S.R., CHEN, W., PARSA, N., OFFIT, K., LOUIE, D.C., DALLA-FAVERA, R. and CHAGANTI, R.S. (1998). Involvement of BCL6 in chromosomal aberrations affecting band 3q27 in B-cell non-Hodgkin lymphoma. Genes Chromosomes Cancer 23: 323-327.

CHO, S., LEE, J.H., CHO, S.B., YOON, K.W., PARK, S.Y., LEE, W.S., PARK, C.H., JOO, Y.E., KIM, H.S., CHOI, S.K. et al., (2010). Epigenetic methylation and expression of caspase 8 and survivin in hepatocellular carcinoma. Pathol Int 60: 203-211.

$\mathrm{CHO}$, Y.S. (2014). Perspectives on the therapeutic modulation of an alternative cell death, programmed necrosis (review). Int J Mol Med 33: 1401-1406.

DAWSON, S.J., MAKRETSOV, N., BLOWS, F.M., DRIVER, K.E., PROVENZANO, E. LE QUESNE, J., BAGLIETTO, L., SEVERI, G., GILES, G.G., MCLEAN, C.A. et al., (2010). BCL2 in breast cancer: a favourable prognostic marker across molecular subtypes and independent of adjuvant therapy received. BrJ Cancer 103:668-675.

DEGTEREV, A., HUANG, Z., BOYCE, M., LI, Y., JAGTAP, P., MIZUSHIMA, N., CUNY G.D., MITCHISON, T.J., MOSKOWITZ, M.A. and YUAN, J. (2005). Chemical inhibitor of nonapoptotic cell death with therapeutic potential for ischemic brain injury. Nat Chem Biol 1: 112-119.

DEMIROVIC, A., ULAMEC, M., BEZJAK, M., BELICZA, M. and KRUŠLIN, B. (2014). Apoptotic markers (P53, Bcl-2 and Bax) expression in renal oncocytoma and chromophobe renal cell carcinoma. Periodicum biologorum 116: 173-176.

DEYHIMI, P. and TAVAKOLI, P. (2013). Study of apoptosis in oral pemphigus vulgaris using immunohistochemical marker Bax and TUNEL technique. J Oral Pathol Med 42: 409-414.

DOGAN, A., BAGDI, E., MUNSON, P. and ISAACSON, P.G. (2000). CD10 and BCL-6 expression in paraffin sections of normal lymphoid tissue and B-cell lymphomas. Am J Surg Pathol 24: 846-852.

DONIZY, P., HALON, A., SUROWIAK, P., PIETRZYK, G., KOZYRA, C. and MATKOWSKI, R. (2013). Correlation between PARP-1 immunoreactivity and cytomorphological features of parthanatos, a specific cellular death in breast cancer cells. Eur J Histochem 57: e35.

EGLE, A., HARRIS, A.W., BATH, M.L., O'REILLY, L. and CORY, S. (2004). VavP$\mathrm{Bcl} 2$ transgenic mice develop follicular lymphoma preceded by germinal center hyperplasia. Blood 103: 2276-2283. 
EGUCHI, K. (2001). Apoptosis in autoimmune diseases. Intern Med 40: 275-284.

ELMORE, S. (2007). Apoptosis: a review of programmed cell death. Toxicol Pathol 35: 495-516.

ENTEZARI, M., ZAKERI, Z. and LOCKSHIN, R.A. (2010). Apoptosis in Developmental Processes. In Encyclopedia of Life Sciences (ELS). John Wiley \& Sons, Ltd, Chichester.

ESER, B., SARI, I., CANOZ, O., ALTUNTAS, F., CAKMAK, E., OZTURK, A., OZKAN, M., ER, O., CETIN, M. and UNAL, A. (2006). Prognostic significance of Fas (CD95/ APO-1) positivity in patients with primary nodal diffuse large B-cell lymphoma. Am J Hematol 81: 307-314.

FAVALORO, B., ALLOCATI, N., GRAZIANO, V., DI ILIO, C. and DE LAURENZI, V. (2012). Role of apoptosis in disease. Aging (Albany NY) 4: 330-349.

FRISCH, S.M. and FRANCIS, H. (1994). Disruption of epithelial cell-matrix interactions induces apoptosis. J Cell Biol 124: 619-626.

FU, D.R., KATO, D., WATABE, A., ENDO, Y. and KADOSAWA, T. (2014). Prognostic Utility of Apoptosis Index, Ki-67 and Survivin Expression in Dogs with Nasal Carcinoma Treated with Orthovoltage Radiation Therapy. J VetMed Sci. 76: 1505-1512.

FUCHS, Y. and STELLER, H. (2011). Programmed cell death in animal development and disease. Cell 147: 742-758.

GALLUZZI, L.BRAVO-SAN PEDRO, J.M.VITALE, I.AARONSON, S.A.ABRAMS, J.M.ADAM, D.ALNEMRI, E.S.ALTUCCI, L.ANDREWS, D.ANNICCHIARICOPETRUZZELLI, M. etal., (2015). Essential versus accessory aspects of cell death: recommendations of the NCCD 2015. Cell Death Differ. 22: 58-73.

GALLUZZI, L., MAIURI, M.C., VITALE, I., ZISCHKA, H., CASTEDO, M., ZITVOGEL, L. and KROEMER, G. (2007). Cell death modalities: classification and pathophysiological implications. Cell Death Differ 14: 1237-1243.

GALLUZZI, L., VITALE, I., ABRAMS, J.M., ALNEMRI, E.S., BAEHRECKE, E.H., BLAGOSKLONNY, M.V., DAWSON, T.M., DAWSON, V.L., EL-DEIRY, W.S., FULDA, S. et al., (2012). Molecular definitions of cell death subroutines: recommendations of the Nomenclature Committee on Cell Death 2012. Cell Death Differ 19: 107-120.

GASCOYNE, R.D., KRAJEWSKA, M., KRAJEWSKI, S., CONNORS, J.M. and REED, J.C. (1997). Prognostic significance of Bax protein expression in diffuse aggressive non-Hodgkin's lymphoma. Blood 90: 3173-3178.

GATTUSO, P. (2009). Differential Diagnosis in Surgical Pathology. Saunders/Elsevier.

GERBER, A., BOHNE, M., RASCH, J., STRUY, H., ANSORGE, S. and GOLLNICK, H. (2000). Investigation of annexin V binding to lymphocytes after extracorporeal photoimmunotherapy as an early marker of apoptosis. Dermatology201: 111-117.

GHAVAMI, S., SHOJAEI, S., YEGANEH, B., ANDE, S.R., JANGAMREDDY, J.R., MEHRPOUR, M., CHRISTOFFERSSON, J., CHAABANE, W., MOGHADAM, A.R., KASHANI, H.H. et al., (2014). Autophagy and apoptosis dysfunction in neurodegenerative disorders. Prog Neurobiol 112: 24-49.

GKOGKOU, C., FRANGIA, K., SAIF, M.W., TRIGIDOU, R. and SYRIGOS, K. (2014). Necrosis and apoptotic index as prognostic factors in non-small cell lung carcinoma: a review. Springerplus 3: 120.

GOBE, G., RUBIN, M., WILLIAMS, G., SAWCZUK, I. and BUTTYAN, R. (2002). Apoptosis and expression of $\mathrm{Bcl}-2, \mathrm{Bcl}-\mathrm{XL}$, and $\mathrm{Bax}$ in renal cell carcinomas. Cancer Invest 20: 324-332.

GOWN, A.M. and WILLINGHAM, M.C. (2002). Improved detection of apoptotic cells in archival paraffin sections: immunohistochemistry using antibodies to cleaved caspase 3. J Histochem Cytochem 50: 449-454.

GREEN, D.R., GALLUZZI, L. and KROEMER, G. (2011). Mitochondria and the autophagy-inflammation-cell death axis in organismal aging. Science 333: 1109-1112

HAHNE, M., RIMOLDI, D., SCHROTER, M., ROMERO, P., SCHREIER, M., FRENCH, L.E., SCHNEIDER, P., BORNAND, T., FONTANA, A., LIENARD, D. et al., (1996) Melanoma cell expression of Fas(Apo-1/CD95) ligand: implications for tumor immune escape. Science 274: 1363-1366.

HAN, H., LANDRENEAU, R.J., SANTUCCI, T.S., TUNG, M.Y., MACHEREY, R.S. SHACKNEY, S.E., STURGIS, C.D., RAAB, S.S. and SILVERMAN, J.F. (2002). Prognostic value of immunohistochemical expressions of p53, HER-2/neu, and bcl-2 in stage I non-small-cell lung cancer. Hum Pathol 33: 105-110.

HANAHAN, D. and WEINBERG, R.A. (2011). Hallmarks of cancer: the next generation. Cell 144: 646-674.

HANS, C.P., WEISENBURGER, D.D., GREINER, T.C., GASCOYNE, R.D., DELABIE, J., OTT, G., MULLER-HERMELINK, H.K., CAMPO, E., BRAZIEL, R.M., JAFFE, E.S. etal., (2004). Confirmation of the molecular classification of diffuse large B-cell lymphoma by immunohistochemistry using a tissue microarray. Blood 103:275-282.

HAUPT, S., BERGER, M., GOLDBERG, Z. and HAUPT, Y. (2003). Apoptosis - the p53 network. J Cell Sci 116: 4077-4085.

HAV, M., LIBBRECHT, L., FERDINANDE, L., PATTYN, P., LAURENT, S., PEETERS, M., PRAET, M. and PAUWELS, P. (2011). MDM2 gene amplification and protein expressions in colon carcinoma: is targeting MDM2 a new therapeutic option? Virchows Arch 458: 197-203.

HEMANN, M.T. and LOWE, S.W. (2006). The p53-Bcl-2 connection. Cell Death Differ 13: 1256-1259.

HOFFMAN, W.H., BIADE, S., ZILFOU, J.T., CHEN, J. and MURPHY, M. (2002). Transcriptional repression of the anti-apoptotic survivin gene by wild type p53. $J$ Biol Chem 277: 3247-3257.

HOLDENRIEDER, S. and STIEBER, P. (2004). Apoptotic markers in cancer. Clin Biochem 37: 605-17.

HORVITZ, H.R. (1999). Genetic control of programmed cell death in the nematode Caenorhabditis elegans. Cancer Res 59: 1701s-1706s.

HOTCHKISS, R.S., STRASSER, A., MCDUNN, J.E. and SWANSON, P.E. (2009) Cell death. N Engl J Med 361: 1570-1583.

HUANG, W.Y., DAVIES, G.L. and DAVIS, J.J. (2013). Engineering cytochrome-modified silica nanoparticles to induce programmed cell death. Chemistry 19: 17891-17898.

IQBAL, J., MEYER, P.N., SMITH, L.M., JOHNSON, N.A., VOSE, J.M., GREINER T.C., CONNORS, J.M., STAUDT, L.M., RIMSZA, L., JAFFE, E. et al., (2011) $\mathrm{BCL2}$ predicts survival in germinal center $\mathrm{B}$-cell-like diffuse large $\mathrm{B}$-cell lymphoma treated with CHOP-like therapy and rituximab. Clin Cancer Res 17: 7785-7795.

ITO, Y. and OTSUKI, Y. (1998). Localization of apoptotic cells in the human epidermis by an in situ DNA nick end-labeling method using confocal reflectant laser microscopy. J Histochem Cytochem 46: 783-786.

JACOBSON, M.D., WEIL, M. and RAFF, M.C. (1997). Programmed cell death in animal development. Cell 88: 347-354

JERUC, J., VIZJAK, A., ROZMAN, B. and FERLUGA, D. (2006). Immunohistochemical expression of activated caspase-3 as a marker of apoptosis in glomeruli of human lupus nephritis. Am J Kidney Dis 48: 410-418.

JIA, Y., DONG, B., TANG, L., LIU, Y., DU, H., YUAN, P., WU, A. and JI, J. (2012) Apoptosis index correlates with chemotherapy efficacy and predicts the survival of patients with gastric cancer. Tumour Biol 33: 1151-1158.

JIANG, P. and YUE, Y. (2014). Human papillomavirus oncoproteins and apoptosis (Review). Exp Ther Med 7: 3-7.

JOHNSTONE, R.W., FREW, A.J. and SMYTH, M.J. (2008). The TRAIL apoptotic pathway in cancer onset, progression and therapy. Nat Rev Cancer 8: 782-798.

JORDAN, D., HINDOCHA, S., DHITAL, M., SALEH, M. and KHAN, W. (2012). The epidemiology, genetics and future management of syndactyly. Open Orthop $J$ 6: 14-27.

KACZMAREK, A., VANDENABEELE, P. and KRYSKO, D.V. (2013). Necroptosis: the release of damage-associated molecular patterns and its physiological relevance. Immunity 38: 209-223.

KELLY, P.N. and STRASSER, A. (2011). The role of Bcl-2 and its pro-survival relatives in tumourigenesis and cancer therapy. Cell Death Differ 18: 1414-1424.

KEMP, C.J., SUN, S. and GURLEY, K.E. (2001). p53 induction and apoptosis in response to radio- and chemotherapy in vivo is tumor-type-dependent. Cancer Res 61: 327-332.

KERR, J.F. (1965). A histochemical study of hypertrophy and ischaemic injury of rat liver with special reference to changes in lysosomes. J Pathol Bacteriol 90: 419-435.

KERR, J.F. (2002). History of the events leading to the formulation of the apoptosis concept. Toxicology 181-182: 471-474.

KERR, J.F., WYLLIE, A.H. and CURRIE, A.R. (1972). Apoptosis: a basic biological phenomenon with wide-ranging implications in tissue kinetics. $\mathrm{Br} J$ Cancer 26 : 239-257.

KHOURY, T., ARSHAD, A., BOGNER, P., RAMNATH, N., ZHANG, S., CHAN DRASEKHAR, R., WILDING, G., ALRAWI, S. and TAN, D. (2009). Apoptosisrelated (survivin, Bcl-2), tumor suppressor gene (p53), proliferation (Ki-67) and non-receptor tyrosine kinase (Src) markers expression and correlation with clinicopathologic variables in 60 thymic neoplasms. Chest 136: 220-228.

KIM, Y.J., YI, Y., SAPP, E., WANG, Y., CUIFFO, B., KEGEL, K.B., QIN, Z.H., ARONIN, N. and DIFIGLIA, M. (2001). Caspase 3-cleaved N-terminal fragments of wild-type and mutant huntingtin are present in normal and Huntington's disease 
brains, associate with membranes, and undergo calpain-dependent proteolysis. Proc Natl Acad Sci USA 98: 12784-12789.

KITANAKA, C. and KUCHINO, Y. (1999). Caspase-independent programmed cell death with necrotic morphology. Cell Death Differ 6: 508-515.

KRAUS, M.D. and HALEY, J. (2000). Lymphocyte predominance Hodgkin's disease: the use of bcl-6 and CD57 in diagnosis and differential diagnosis. Am J Surg Pathol 24: 1068-1078.

KROEMER, G., EL-DEIRY, W.S., GOLSTEIN, P., PETER, M.E., VAUX, D., VANDENABEELE, P., ZHIVOTOVSKY, B., BLAGOSKLONNY, M.V., MALORNI, W., KNIGHT, R.A. et al., (2005). Classification of cell death: recommendations of the Nomenclature Committee on Cell Death. Cell Death Differ 12 Suppl 2: 1463-1467.

KROEMER, G., GALLUZZI, L., VANDENABEELE, P., ABRAMS, J., ALNEMRI, E.S., BAEHRECKE, E.H., BLAGOSKLONNY, M.V., EL-DEIRY, W.S., GOLSTEIN, P., GREEN, D.R. et al., (2009). Classification of cell death: recommendations of the Nomenclature Committee on Cell Death 2009. Cell Death Differ 16: 3-11.

KUMAR, V., ABBAS, A.K. and ASTER, J.C. (2013). Robbins basic pathology, (9th ed.) Philadelphia, PA: Elsevier/Saunders.

KURIYAMA, H., LAMBORN, K.R., O'FALLON, J.R., ITURRIA, N., SEBO, T., SCHAEFER, P.L., SCHEITHAUER, B.W., BUCKNER, J.C., KURIYAMA, N., JENKINS, R.B. et al., (2002). Prognostic significance of an apoptotic index and apoptosis/ proliferation ratio for patients with high-grade astrocytomas. Neuro Oncol4:179-186.

LEE, J.Y., CHO, K.S., DIAZ, R.R., CHOI, Y.D. and CHOI, H.Y. (2015). p53 Expression as a Prognostic Factor in Upper Urinary Tract Urothelial Carcinoma: A Systematic Review and Meta-Analysis. Urol Int. 94: 50-57.

LEVINE, A.J. and OREN, M. (2009). The first 30 years of p53: growing ever more complex. Nat Rev Cancer 9: 749-758.

LIU, Y. and LEVINE, B. (2015). Autosis and autophagic cell death: the dark side of autophagy. Cell Death Differ. 22: 367-376.

LOCKSHIN, R.A. and WILLIAMS, C.M. (1965). Programmed Cell Death--I. Cytology of Degeneration in the Intersegmental Muscles of the Pernyi Silkmoth. J Insect Physiol 11: 123-133.

MACWHINNIE, N. and MONAGHAN, H. (2004). The use of P53, PTEN, and C-erbB-2 to differentiate uterine serous papillary carcinoma from endometrioid endometrial carcinoma. Int J Gynecol Cancer 14: 938-946.

MADKAIKAR, M., MHATRE, S., GUPTA, M. and GHOSH, K. (2011). Advances in autoimmune lymphoproliferative syndromes. Eur J Haematol 87: 1-9.

MAJNO, G. and JORIS, I. (1995). Apoptosis, oncosis, and necrosis. An overview of cell death. Am J Pathol 146: 3-15.

MATTSON, M.P. (2000). Apoptosis in neurodegenerative disorders. Nat Rev Mol Cell Biol 1: 120-129.

MCKENNEY, J.K., DESAI, S., COHEN, C. and AMIN, M.B. (2001). Discriminatory immunohistochemical staining of urothelial carcinoma in situ and non-neoplastic urothelium: an analysis of cytokeratin 20, p53, and CD44 antigens. Am J Surg Pathol 25: 1074-1078.

MCNEES, A.L. and GOODING, L.R. (2002). Adenoviral inhibitors of apoptotic cell death. Virus Res 88: 87-101.

MURPHY, F.J., HAYES, I. and COTTER, T.G. (2003a). Targeting inflammatory diseases via apoptotic mechanisms. Curr Opin Pharmacol 3: 412-419.

MURPHY, F.J., SEERY, L.T. and HAYES, I. (2003b). Therapeutic approaches to the modulation of apoptosis. Essays Biochem 39: 131-153.

NAGATA, S. (2007). Autoimmune diseases caused by defects in clearing dead cells and nuclei expelled from erythroid precursors. Immunol Rev 220: 237-250.

NIJHAWAN, D., HONARPOUR, N. and WANG, X. (2000). Apoptosis in neural development and disease. Annu Rev Neurosci 23: 73-87.

O'ROURKE, M.G. and ELLEM, K.A. (2000). John Kerr and apoptosis. Med J Aust 173: 616-617.

ONDROUSKOVA, E., SOUCEK, K., HORVATH, V. and SMARDA, J. (2008). Alternative pathways of programmed cell death are activated in cells with defective caspase-dependent apoptosis. Leuk Res 32: 599-609.

OPFERMAN, J.T. (2008). Apoptosis in the development of the immune system. Cell Death Differ 15: 234-242.

OTSUKI, Y., LI, Z. and SHIBATA, M.A. (2003). Apoptotic detection methods--from morphology to gene. Prog Histochem Cytochem 38: 275-339.

OUYANG, L., SHI, Z., ZHAO, S., WANG, F.T., ZHOU, T.T., LIU, B. and BAO, J.K.
(2012). Programmed cell death pathways in cancer: a review of apoptosis, autophagy and programmed necrosis. Cell Prolif 45: 487-498.

OVERHOLTZER, M., MAILLEUX, A.A., MOUNEIMNE, G., NORMAND, G., SCHNITT, S.J., KING, R.W., CIBAS, E.S. and BRUGGE, J.S. (2007). A nonapoptotic cell death process, entosis, that occurs by cell-in-cell invasion. Cell 131: 966-979.

OZSAN, N., BEDKE, B.J., LAW, M.E., INWARDS, D.J., KETTERLING, R.P., KNUDSON R.A., KEENEY, G.L., DOGAN, A. and FELDMAN, A.L. (2011). Clinicopathologic and genetic characterization of follicular lymphomas presenting in the ovary reveals 2 distinct subgroups. Am J Surg Pathol 35: 1691-1699.

PALMERINI, F., DEVILARD, E., JARRY, A., BIRG, F. and XERRI, L. (2001). Caspase 7 downregulation as an immunohistochemical marker of colonic carcinoma. Hum Pathol 32: 461-467.

PARK, S.H., MIN, H., CHI, J.G., PARK, K.W., YANG, H.R. and SEO, J.K. (2005) Immunohistochemical studies of pediatric intestinal pseudo-obstruction: bcl2, a valuable biomarker to detect immature enteric ganglion cells. Am J Surg Pathol 29: 1017-1024.

PASINELLI, P., HOUSEWEART, M.K., BROWN, R.H., JR. and CLEVELAND, D.W. (2000). Caspase-1 and -3 are sequentially activated in motor neuron death in $\mathrm{Cu}, \mathrm{Zn}$ superoxide dismutase-mediated familial amyotrophic lateral sclerosis. Proc Natl Acad Sci USA 97: 13901-13906.

PAULEAU, A.L., LAROCHETTE, N., GIORDANETTO, F., SCHOLZ, S.R., PONCET, D., ZAMZAMI, N., GOLDMACHER, V.S. and KROEMER, G. (2007). Structurefunction analysis of the interaction between Bax and the cytomegalovirus-encoded protein vMIA. Oncogene 26: 7067-7080

PENALOZA, C., LIN, L., LOCKSHIN, R.A. and ZAKERI, Z. (2006). Cell death in development: shaping the embryo. Histochem Cell Biol 126: 149-158.

PIETSCH, E.C., SYKES, S.M., MCMAHON, S.B. and MURPHY, M.E. (2008). The p53 family and programmed cell death. Oncogene 27: 6507-6521.

REED, J.C. (1997). Bcl-2 family proteins: regulators of apoptosis and chemoresistance in hematologic malignancies. Semin Hematol 34: 9-19.

REMIJSEN, Q., KUIJPERS, T.W., WIRAWAN, E., LIPPENS, S., VANDENABEELE, P. and VANDEN BERGHE, T. (2011). Dying for a cause: NETosis, mechanisms behind an antimicrobial cell death modality. Cell Death Differ 18: 581-588.

RIBEIRO MDE, C., COUTINHO, L.M. and HILBIG, A. (2004). The role of apoptosis, cell proliferation index, bcl-2, and p53 in glioblastoma prognosis. Arq Neuropsiquiatr 62: 262-270.

RICHTER, E.N., OEVERMANN, K., BUENTIG, N., STORKEL, S., DALLMANN, I. and ATZPODIEN, J. (2002). Primary apoptosis as a prognostic index for the classification of metastatic renal cell carcinoma. J Urol 168: 460-464.

ROHN, T.T. (2010). The role of caspases in Alzheimer's disease; potential novel therapeutic opportunities. Apoptosis 15: 1403-1409.

ROSS, W.A. (2005). Treatment of Gastrointestinal Acute Graft-Versus-Host Disease. Curr Treat Options Gastroenterol 8: 249-258.

ROSS, W.A. and COURIEL, D. (2005). Colonic graft-versus-host disease. Curr Opin Gastroenterol 21: 64-69.

SABINE, V.S., FARATIAN, D., KIRKEGAARD-CLAUSEN, T. and BARTLETT, J.M (2012). Validation of activated caspase-3 antibody staining as a marker of apoptosis in breast cancer. Histopathology 60: 369-371.

SCHWEICHEL, J.U. and MERKER, H.J. (1973). The morphology of various types of cell death in prenatal tissues. Teratology 7: 253-266.

SHANMUGAM, M.P., LAKSHMI, A., BISWAS, J. and KRISHNAKUMAR, S. (2003). Prognostic significance of Fas expression in retinoblastoma. Ocul Immunol Inflamm 11: 107-113

SHIMIZU, S., YOSHIDA, T., TSUJIOKA, M. and ARAKAWA, S. (2014). Autophagic cell death and cancer. Int $J$ Mol Sci 15: 3145-3153.

SHIN, M.S., KIM, H.S., LEE, S.H., LEE, J.W., SONG, Y.H., KIM, Y.S., PARK, W.S., KIM, S.Y., LEE, S.N., PARK, J.Y. et al., (2002). Alterations of Fas-pathway genes associated with nodal metastasis in non-small cell lung cancer. Oncogene 21 : 4129-4136.

SIMUNOVIC, F., YI, M., WANG, Y., MACEY, L., BROWN, L.T., KRICHEVSKY, A.M., ANDERSEN, S.L., STEPHENS, R.M., BENES, F.M. and SONNTAG, K.C. (2009). Gene expression profiling of substantia nigra dopamine neurons: further insights into Parkinson's disease pathology. Brain 132: 1795-1809.

SULSTON, J.E., SCHIERENBERG, E., WHITE, J.G. and THOMSON, J.N. (1983) The embryonic cell lineage of the nematode Caenorhabditis elegans. Dev Biol 
100: 64-119.

SULZYC-BIELICKA, V., DOMAGALA, P., HYBIAK, J., MAJEWICZ-BRODA, A., SAFRANOW, K. and DOMAGALA, W. (2012). Colorectal cancers differ in respect of PARP-1 protein expression. Pol J Pathol 63: 87-92.

TAKESHITA, M., IMAYAMA, S., OSHIRO, Y., KURIHARA, K., OKAMOTO, S., MATSUKI, Y., NAKASHIMA, Y., OKAMURA, T., SHIRATSUCHI, M., HAYASHI, T. et al., (2004). Clinicopathologic analysis of 22 cases of subcutaneous panniculitis-like CD56- or CD56+ lymphoma and review of 44 other reported cases. Am J Clin Pathol 121: 408-416.

TAWFIK, K., KIMLER, B.F., DAVIS, M.K., FAN, F. and TAWFIK, O. (2012). Prognostic significance of $\mathrm{Bcl}-2$ in invasive mammary carcinomas: a comparative clinicopathologic study between "triple-negative" and non-"triple-negative"tumors. Hum Pathol 43: 23-30.

THOMPSON, B., SALZMAN, D., STEINHAUER, J., LAZENBY, A.J. and WILCOX, C.M. (2006). Prospective endoscopic evaluation for gastrointestinal graft-versushost disease: determination of the best diagnostic approach. Bone Marrow Transplant 38: 371-376.

VAKIFAHMETOGLU, H., OLSSON, M. and ZHIVOTOVSKY, B. (2008). Death through a tragedy: mitotic catastrophe. Cell Death Differ 15: 1153-1162.

VAN HEERDE, W.L., ROBERT-OFFERMAN, S., DUMONT, E., HOFSTRA, L., DOEVENDANS, P.A., SMITS, J.F., DAEMEN, M.J. and REUTELINGSPERGER, C.P. (2000). Markers of apoptosis in cardiovascular tissues: focus on Annexin V. Cardiovasc Res 45: 549-559.

VANDEN BERGHE, T., LINKERMANN, A., JOUAN-LANHOUET, S., WALCZAK, H. and VANDENABEELE, P. (2014). Regulated necrosis: the expanding network of non-apoptotic cell death pathways. Nat Rev Mol Cell Biol 15: 135-147.

VANDENABEELE, P., GALLUZZI, L., VANDEN BERGHE, T. and KROEMER, G. (2010). Molecular mechanisms of necroptosis: an ordered cellular explosion. Nat Rev Mol Cell Biol 11: 700-714.

VANDENABEELE, P., VANDEN BERGHE, T. and FESTJENS, N. (2006). Caspase inhibitors promote alternative cell death pathways. Sci STKE 2006: pe44.

VAUX, D.L. and KORSMEYER, S.J. (1999). Cell death in development. Cell96:245-254.

VERBEKE, C.S., WENTHE, U., GROBHOLZ, R. and ZENTGRAF, H. (2001). Fas ligand expression in Hodgkin lymphoma. Am J Surg Pathol 25: 388-394.

VINCE, J.E. and SILKE, J. (2009). Apoptosis: Regulatory Genes and Disease. In Encyclopedia of Life Sciences (ELS). John Wiley \& Sons, Ltd, Chichester.

VITALE, I., GALLUZZI, L., CASTEDO, M. and KROEMER, G. (2011). Mitotic catastrophe: a mechanism for avoiding genomic instability. Nat Rev Mol Cell Biol 12: 385-392.
WANG, K. (2014). Molecular mechanisms of liver injury: apoptosis or necrosis. Exp Toxicol Pathol 66: 351-356.

WANG, W.S., CHEN, P.M., WANG, H.S., LIANG, W.Y. and SU, Y. (2006). Matrix metalloproteinase-7 increases resistance to Fas-mediated apoptosis and is a poor prognostic factor of patients with colorectal carcinoma. Carcinogenesis 27: 1113-1120.

WEINBERG, O.K., MA, L., SEO, K., BECK, A.H., PAI, R.K., MORALES, A., KIM, Y., SUNDRAM, U., TAN, D., HORNING, S.J. et al., (2009). Low stage follicular lymphoma: biologic and clinical characterization according to nodal or extranodal primary origin. Am J Surg Pathol 33: 591-598.

WHELAN, R.S., KAPLINSKIY, V. and KITSIS, R.N. (2010). Cell death in the pathogenesis of heart disease: mechanisms and significance. Annu Rev Physiol 72: 19-44.

WONG, R.S. (2011). Apoptosis in cancer: from pathogenesis to treatment. J Exp Clin Cancer Res 30: 87.

WU, A., JIA, Y., DONG, B., TANG, L., LIU, Y., DU, H., YUAN, P., DONG, P. and JI, J. (2014a). Apoptosis and KI 67 index correlate with preoperative chemotherapy efficacy and better predict the survival of gastric cancer patients with combined therapy. Cancer Chemother Pharmacol 73: 885-893.

WU, W., ZHU, H., LIANG, Y., KONG, Z., DUAN, X., LI, S., ZHAO, Z., YANG, D. and ZENG, G. (2014b). Expression of PARP-1 and its active polymer PAR in prostate cancer and benign prostatic hyperplasia in Chinese patients. Int Urol Nephrol 46: 1345-1349.

WU, X., CHENG, B., CAI, Z.D. and LOU, L.M. (2013). Determination of the apoptotic index in osteosarcoma tissue and its relationship with patients prognosis. Cancer Cell Int 13: 56.

WYLLIE, A.H., KERR, J.F. and CURRIE, A.R. (1980). Cell death: the significance of apoptosis. Int Rev Cytol 68: 251-306.

XU, B., ZHOU, Z.G., LI, Y., WANG, L., YANG, L., ZHOU, B., LIU, H.Y., SONG, J.M. ZENG, Y.J., WANG, R. etal., (2008). Clinicopathological significance of caspase-8 and caspase-10 expression in rectal cancer. Oncology 74: 229-236.

XU, X.L., ZHENG, W.H., TAO, K.Y., LI, X.X., XU, W.Z., WANG, Y., ZHU, S.M. and MAO, W.M. (2014). p53 is an independent prognostic factor in operable esophageal squamous cell carcinoma: a large-scale study with a long follow-up. Med Oncol 31: 257

YAMANA, K., BILIM, V., HARA, N., KASAHARA, T., ITOI, T., MARUYAMA, R., NISHIYAMA, T., TAKAHASHI, K. and TOMITA, Y. (2005). Prognostic impact of FAS/ CD95/APO-1 in urothelial cancers: decreased expression of Fas is associated with disease progression. Br J Cancer 93: 544-551.

ZHOU, W. and YUAN, J. (2014). Necroptosis in health and diseases. Semin Cell Dev Biol 35C: 14-23. 


\section{Further Related Reading, published previously in the Int. J. Dev. Biol.}

Revisiting DNA damage repair, p53-mediated apoptosis and cisplatin sensitivity in germ cell tumors Francesca Cavallo, Darren R. Feldman and Marco Barchi

Int. J. Dev. Biol. (2013) 57: 273-280

http://dx.doi.org/10.1387/ijdb.130135mb

Causes and consequences of apoptosis in spermatozoa; contributions to infertility and impacts on development R. John Aitken and Mark A. Baker

Int. J. Dev. Biol. (2013) 57: 265-272

http://dx.doi.org/10.1387/ijdb.130146ja

Regulation of programmed cell death during neural induction in the chick embryo Anna Gibson, Neil Robinson, Andrea Streit, Guojun Sheng and Claudio D. Stern

Int. J. Dev. Biol. (2011) 55: 33-43

http://dx.doi.org/10.1387/ijdb.103233sg

Life-giving caspases: revealing new roles during mouse embryo preimplantation development

Dolores Busso, Calixto Dominguez, Tomas Perez-Acle and Ricardo D. Moreno

Int. J. Dev. Biol. (2010) 54: 857-865

http://dx.doi.org/10.1387/ijdb.092921db

Key apoptosis regulating proteins are down-regulated during postnatal tissue development

Shane D. Madden, Maryanne Donovan and Thomas G. Cotter

Int. J. Dev. Biol. (2007) 51: 415-424

http://dx.doi.org/10.1387/ijdb.062263sm

5 yr ISI Impact Factor $(2013)=2.879$
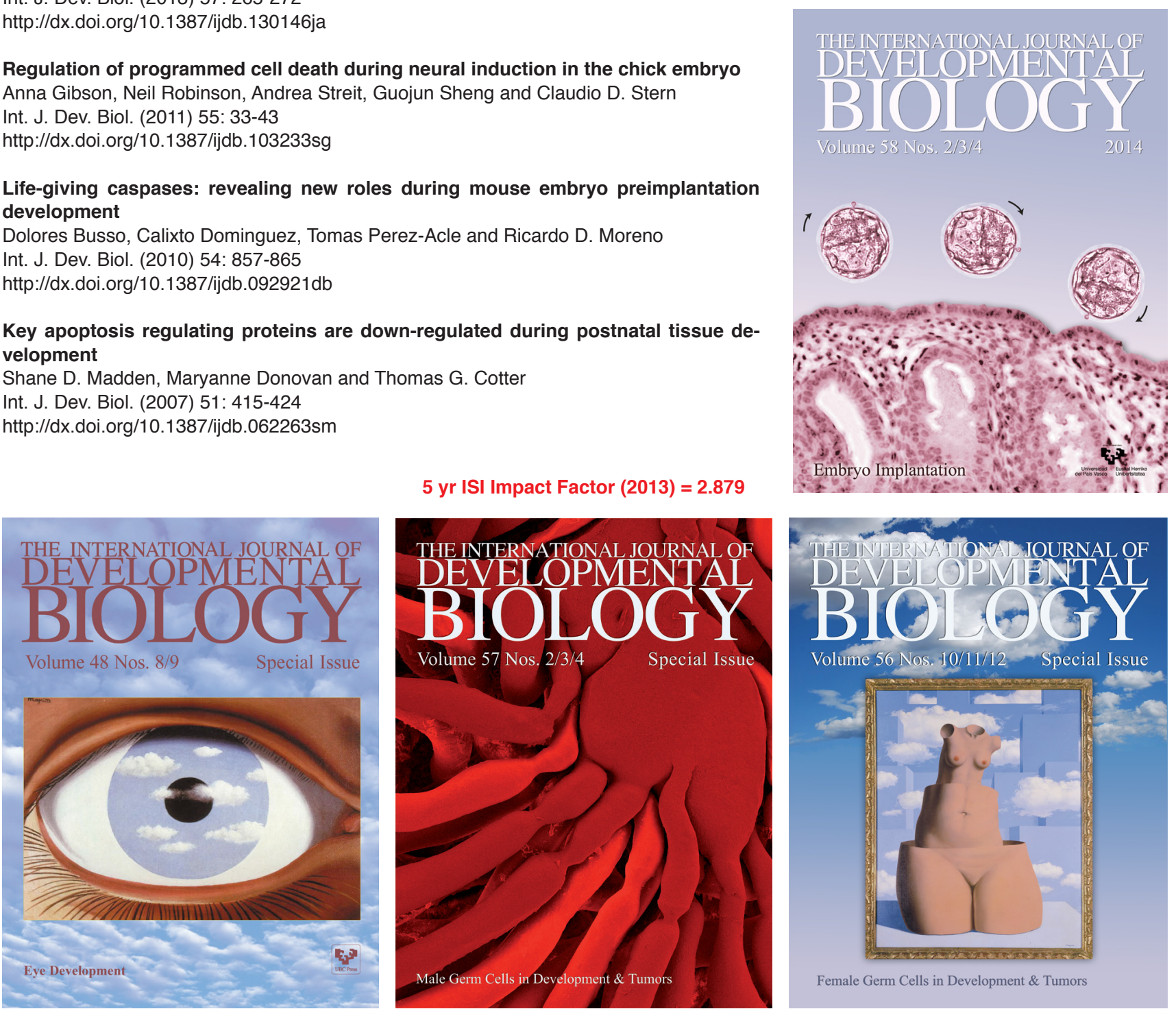